\title{
CYTOTOXICITY AND GENOTOXICITY OF MELTING SNOW - A CASE STUDY OF THE SHUMEN REGION, BULGARIA Teodora Koynova ${ }^{1}$, Asya Dragoeva ${ }^{2}$, Vanya Koleva ${ }^{3}$
}

\begin{abstract}
The presence of atmospheric pollutants is regularly screened in Bulgaria. However, studies on the cytotoxic and genotoxic potential of air contaminants are scarce. Snow collects pollutants from the air. The aim of the present study was to evaluate the effects of melted snow samples from Shumen region (Bulgaria) on mitotic cells using the A. cepa test.

Samples were taken from three open spaces: 1) the city of Shumen, 2) a meadow on the Shumen plateau and 3) agricultural land located about $9.5 \mathrm{~km}$ northeast of the town of Shumen.

The samples from the Shumen city and Shumen plateau indicated the presence of water soluble cytotoxic compounds. The lack of cytotoxicity in the sample from the agricultural land was established. This proves an anthropogenic origin of cytotoxic pollutions at the other two places. These results could serve as warning signals for health preventive programs regarding air quality in Shumen and the Nature Park Shumen plateau during the winter.
\end{abstract}

UDC Classification: 502/504; DOI: http://dx.doi.org/10.12955/cbup.v6.1303

Keywords: air pollution, snow contaminants, cytotoxicity, genotoxicity, Allium cepa test

\section{Introduction}

Nowadays air pollution is considered as serious health risk (Calderon-Garciduenas et al., 2002; Hudson et al., 2006; Samet \& Krewski, 2007). The presence of atmospheric pollutants is regularly screened in Bulgaria. It is well known that air contains a complex mixtures of different chemicals. Amongst them particulate matter (PM) pollution has a negative impact on human health (Cai et al., 2017, Rai, 2016). In Shumen city (Northeast Bulgaria) the content of PM10 has been significantly elevated during winter (Regional Inspectorate of Environment and Water Shumen, 2016). Home heating is considered to be the main source of this kind of pollution in the town. In addition, permanent winds disseminate air contaminants to a protected area used by citizens for recreation. In this way, both the ecosystem and human health could be affected.

Air contaminants include various chemicals, some of which are genotoxic. It should be noted that the synergistic and antagonistic effects of environmental pollutants lead to the requirement to determine approaches to study a whole mixture rather individual chemicals (Blagojević et al., 2009). Snow collects pollutants from the atmosphere (Lei \& Wania, 2004). So, analysis of melted snow samples could be a useful approach to disclose the genotoxic potential of air contaminants (Blagojević et al., 2009). For this purpose, tests used for evaluating the genotoxicity of water samples could be applied (Majer et al., 2005). The Allium cepa test (Levan, 1938) has been widely used for evaluating the cytotoxic and genotoxic potential of complex mixtures showing close correlation with other testsystems (Grant, 1978; Fiskesjö, 1993; Tedesco \& Laughinghouse IV, 2012).

The aim of the present study was to evaluate the cytotoxic and genotoxic potential of melted snow samples from the Shumen region (Bulgaria) using the A. cepa test.

\section{Materials and Methods}

\section{Studied area and soil sampling}

Shumen is a medium sized town, located in the northeastern part of Bulgaria, around $43^{\circ} 15-16^{\circ}$ latitude north and 26 $54-58^{\circ}$ longitude east. Low snowfall, low wind from the north-northeast and temperatures below $0^{\circ} \mathrm{C}$ characterized the time period 10 days before the sampling date. The latitude and longitude at the sampling site were recorded using a handheld global positioning system (GPS).

Samples of the snow were collected from three open spaces: 1) Sample from urban area (SU) - in the city of Shumen, at the foot of the Shumen Plateau (altitude $246 \mathrm{~m}$ ); 2) Sample from the Nature Park (SNP) - a meadow near the huge monument on the Shumen plateau (altitude 447 m); 3) Sample from a rural area (SR) - agricultural land in a rural area located about $9.5 \mathrm{~km}$ northeast away from the first sampling site (altitude $243 \mathrm{~m}$ ).

\footnotetext{
${ }^{1}$ Faculty of Natural Sciences, Konstantin Preslavski University of Shumen, Shumen, Bulgaria, t.koynova@abv.bg

${ }^{2}$ Faculty of Natural Sciences, Konstantin Preslavski University of Shumen, Shumen, Bulgaria

${ }^{3}$ Faculty of Natural Sciences, Konstantin Preslavski University of Shumen, Shumen, Bulgaria
} 
Samples were collected from the surface layer of the snow. Ten surface snow sub-samples were taken from each sampling site and bulked to give a composite sample. Sub-samples were taken in an 'Sshape' pattern at a distance of $5 \mathrm{~m}$. Samples were maintained frozen during shipment and were kept in frozen storage at $-20^{\circ} \mathrm{C}$ until the time of analysis. Then snow samples were then melted at room temperature.

\section{Allium cepa-test}

The onion bulbs were purchased from a biofarm certified to the BCS Öko Garantie; GLOBALG.A.P and IFS Food. The outer scales of the bulbs and the old dry roots were removed without destroying the root primordia. The bulbs were kept for root germination in deionized water for $24 \mathrm{~h}$. Bulbs with new roots with length of $1.5 \mathrm{~cm}$ were placed in melted snow and were allowed to root for $24 \mathrm{~h}$ at $25 \pm 1{ }^{\circ} \mathrm{C}$. The root tips were washed thoroughly with distilled water, fixed in a Clarke's fixative $(95 \%$ ethanol: acetic acid glacial, 3:1) for 90 minutes and hydrolyzed in $1 \mathrm{~N} \mathrm{HCl}$ for 8 min and in $45 \%$ acetic acid for $60 \mathrm{~min}$ at room temperature. Then they were stained for $90 \mathrm{~min}$ in $1 \%$ aceto-orcein and the terminal root tips (1-2 mm) were excised and squashed in $45 \% \mathrm{CH}_{3} \mathrm{COOH}$. Each snow sample and control group consisted of 9 meristems from 3 bulbs. At least 1000 cells of each root meristem were analyzed. The mitotic index was determined as a ratio between the number of cells in mitosis and the total number of analyzed cells, expressed as a percentage. The index of each phase of mitotic division was calculated as a ratio between the cell number in the respective period and the number of dividing cells. The frequency of aberrant cells was calculated as a percentage of the total number of analyzed cells. The following abnormalities were scored: mitotic cells with chromosome bridges, fragments, vagrant chromosomes, multipolar anaphase/telophase, diagonal spindle, C-mitosis and interphase cells with micronuclei or two nuclei.

Statistical analysis

Results were expressed as the mean \pm standard deviation (SD) and significance was analyzed using a Student's t-test where significance was accepted at $\mathrm{P} \leq 0.05$.

\section{Results and Discussion}

We evaluated the microscopic cytotoxic effects of melted snow using the Allium cepa-test. Table 1 summarizes the effect of snow samples on the mitotic index and mitotic phase distribution in the root meristematic cells of A. cepa. Upon the treatment with SNP and SU the mitotic division was almost completely inhibited. These results indicate the occurrence of strong cytotoxic effect (Leme \& MarinMorales, 2009). It is impossible to provide a cytogenetic analysis if the mitotic index is very low (Rank, 2003). On the contrary, after treatment with SR, the mitotic index value was similar to the negative control. The only sign for mitotic disturbance is a change in mitotic phase distribution (Table 1). As can be seen from Table 2, the frequency of aberrations upon treatment with SR also was similar to the untreated control.

\begin{tabular}{l} 
Table 1: Mitotic index and phase indices in root meristematic cells of Allium cepa L. exposed to \\
melted snow for 24 h. \\
\hline \begin{tabular}{|l|l|l|l|l|l|}
\hline Sample & $\begin{array}{l}\text { Mitotic index } \\
\mathbf{( \%} \pm \text { SD) }\end{array}$ & $\begin{array}{l}\text { Prophase index } \\
\mathbf{( \%} \pm \text { SD) }\end{array}$ & $\begin{array}{l}\text { Metaphase index } \\
\mathbf{( \%} \pm \text { SD) }\end{array}$ & $\begin{array}{l}\text { Anaphase index } \\
(\% \pm \text { SD) }\end{array}$ & $\begin{array}{l}\text { Telophase index } \\
\mathbf{( \%} \pm \text { SD) }\end{array}$ \\
\hline Control & $4.81 \pm 0.71$ & $61.20 \pm 8.56$ & $17.29 \pm 7.14$ & $6.43 \pm 3.64$ & $15.08 \pm 3.31$ \\
\hline SNP & - & - & - & - & - \\
\hline SU & - & - & - & - & - \\
\hline SR & $4.85 \pm 0.25$ & $66.89 \pm 13.90$ & $16.00 \pm 6.98$ & $7.33 \pm 8.51$ & $9.78 \pm 5.56^{*}$ \\
\hline Control - deionized water. Data are expressed as means \pm SD (standard deviation), *P $\leq 0.05$. \\
\hline
\end{tabular} \\
\hline
\end{tabular}

The present study was based on statistics about Particulate Matter (PM 10) dynamics in the air in the town of Shumen. PM10 are inhalable particles, with diameters that are generally 10 micrometers and smaller (EPA, 2017). Levels of PM are elevated during winter in Shumen city, mainly due to home heating. Unfortunately, our results revealed that anthropogenic pollution affects negatively not only the city, but also the protected park nearby. A possible explanation is the constant wind which disseminates pollution on the park territory. This observation was confirmed by the analysis of the sample from the agricultural area. The lack of cytotoxicity in the sample from agricultural land confirmed the anthropogenic origin of this kind of pollution 


\begin{tabular}{|c|c|c|c|c|c|c|c|c|c|}
\hline \multirow[b]{2}{*}{ Sample } & \multicolumn{7}{|c|}{ Dividing cells } & \multicolumn{2}{|c|}{ Interphase cells } \\
\hline & \begin{tabular}{|l|} 
B \\
$(\%)$ \\
\end{tabular} & $\begin{array}{l}\mathrm{V} \\
(\%) \\
\end{array}$ & $\begin{array}{l}\mathbf{F} \\
(\%)\end{array}$ & $\begin{array}{l}\text { MP } \\
(\%)\end{array}$ & $\begin{array}{l}\mathrm{CM} \\
(\%)\end{array}$ & $\begin{array}{l}\text { DS } \\
(\%)\end{array}$ & $\begin{array}{l}\text { Total } \\
(\% \pm \text { SD })\end{array}$ & $\begin{array}{l}\text { Micronuclei } \\
(\% \pm \text { SD) }\end{array}$ & $\begin{array}{l}\text { Two nuclei } \\
(\% \pm \text { SD) }\end{array}$ \\
\hline Control & 0.22 & 2.22 & 0.00 & 0.00 & 0.00 & 2.66 & $5.10 \pm 3.82$ & $0.04 \pm 0.05$ & $0.13 \pm 0.23$ \\
\hline SNP & - & - & - & - & - & - & - & - & - \\
\hline SU & - & - & - & - & - & - & - & - & - \\
\hline SR & 0.00 & 1.78 & 0.44 & 0.00 & 0.67 & 2.44 & $5.33 \pm 4.80$ & $0.03 \pm 0.05$ & 0.00 \\
\hline
\end{tabular}

As described by Blagojević et al. (2009) the snow accumulates various chemical compounds, but knowledge about their genotoxic potential is scarce. The results of present study confirm observations of the above-mentioned study that the A. cepa test is convenient for the evaluation of air pollution through analysis of melted snow samples.

\section{Conclusion}

The observed microscopic effects of the melted snow samples from Shumen city indicated the presence of water soluble cytotoxic compounds. Similar results were obtained from the site on the Shumen plateau located near to the town. The lack of cytotoxicity in the sample from the agricultural land confirmed the anthropogenic origin of this kind of pollution. These results could serve as warning signals for health preventive programs regarding air quality in Shumen and protected area of the Shumen plateau during winter.

\section{Acknowledgements}

This work has been supported by the Bulgarian Ministry of Education and Science, grant no. RD-08125/06.02.2017.

\section{References}

Blagojević, J., Stamenković, G., \& Vujoševic, M. (2009). Potential genotoxic effects of melted snow from an urban area revealed by the Allium cepa test. Chemosphere, 76, 1344-1347.

Cai, M., Xin, Z., \& Yu, X. (2017). Spatio-temporal variations in PM leaf deposition: A meta-analysis. Environmental Pollution, 231, 207-218.

Calderon-Garciduenas, L., Azzarelli, B., Acuna, H., Garcia, R., Gambling, T.M., Osnaya, N., Monroy, S., Tizapantzi, M.-R., Carson, J.L., Villarreal-Calderon, A., \& Rewcastle, B. (2002). Air pollution and brain damage. Toxicologic Pathology, 30, 373-389.

EPA (2017). Particulate Matter (PM10) Trends Retrieved from: https://www.epa.gov/air-trends/particulate-matter-pm10trends

Fiskesjö, G. (1993). The Allium test in wastewater monitoring. Environmental Toxicology, 8(3), 291-298.

Grant, W. F. (1978). Chromosome Aberrations in Plants as a Monitoring System. Environmental Health Perspectives, 27,37 43.

Hudson, R., Arriola, A., Martinez-Gomez, M., \& Distel, H. (2006). Effect of Air pollution on olfactory function in residents of Mexico City. Chemical Senses, 31, 79-85.

Lei, Y. D., \& Wania, F. (2004). Is rain or snow a more efficient scavenger of organic chemicals? Atmospheric Environment, 38, 3557-3571

Leme, D.M. and Marin-Morales, M.A. (2009). Allium cepa test in environmental monitoring: a review on its application. Mutation Research, 682:71-81.

Levan, A. (1938). The effect of colchicine on root mitoses in Allium. Hereditas, 24, 471-486.

Majer, B. J., Grummt, T., Uhl, M., Knasmuler, \& S. (2005). Use of plant bioassays for the detection of genotoxins in the aquatic environment. Acta Hydroch. Hydrob., 33, 45-55.

Rai, P. K. (2016). Impacts of particulate matter pollution on plants: Implications for environmental biomonitoring. Ecotoxicology and Environmental Safety, 129, 120-36.

Rank, J. (2003). The Method of Allium Anaphase-Telophase Chromosome Aberration Assay. Ekologija Vilnius, 1, 38-42

Regional Inspectorate of Environment and Water Shumen. (2016). Regional Report on the state of the environment in 2016. Retrieved from: http://www.riosv-shumen.eu/index.php?homepage=2\&subnavy=1\&act=91

Samet, J., \& Krewski, D. (2007). Health effects associated with exposure to ambient air pollution. Journal of Toxicology and Environmental Health, 70, 227-242.

Tedesco, S. B., \& Laughinghouse IV, H. D. (2012). Bioindicator of Genotoxicity: The Allium cepa Test. Environmental Contamination. Srivastava J., (Ed.), InTech, pp. 137-156. 